\title{
Influence of Biogeochemical Qualities of Shizuoka Water on the Degradation of PVC Shower Hose
}

\author{
Mst. Shamsun Nahar*, Jing Zhang, Shogo Nakamura \\ Department of Environmental Biology and Chemistry, Graduate School of Science and Engineering, University of Toyama, Gofuku, \\ Toyama, Japan. \\ Email: msnahar@sci.u-toyama.ac.jp
}

Received December 25 $5^{\text {th }}, 2010$; revised February $1^{\text {st }}, 2011$; accepted March $6^{\text {th }}, 2011$.

\begin{abstract}
Recently, it has been report of polyvinyl chloride (PVC) shower hoses becoming hard and brittle throughout the eastern and middle portion of Shizuoka Prefecture, Japan. No reason has been identified for this phenomenon. The affected cities are located at the paper industries area. We have collected the stiffed hoses attached to shower faucets and examined them for chemical changes. In addition, we have analyzed the water quality of 11 affected cities in Shizuoka in an attempt to establish a probable bio-physico-chemical chain reaction that could cause such hose degradation. According to elemental analysis, oxygen-containing carbon-based plasticizers may leach out of the hose. As a result, the hoses lost flexibility after one year of use in Shizuoka. The organic nutrient (1,4-dioxane) was identified by GC-MS and the utmost number of the heterotrophic bacteria has been detected by PCR-DGGE in the shower water of Shizuoka. The study concludes that the plasticizer disappeared from the stiffed hose and the special characteristics of water in Shizuoka, consisting of organic nutrients, can be used for heterotrophic bacterial growth as a energy source at the shower water temperature, which allows prompt utilization of the plasticizer by increasing abundant bacteria, causing the brittleness of the PVC hose.
\end{abstract}

Keywords: Shizuoka Water, Plasticized PVC Hose, Bacterialnutrient, PCR-DGGE, Paper Industries

\section{Introduction}

In a study to identify the bio-chemical process causing damage to PVC shower hoses, the structure and material content of the hoses were thoroughly analyzed. This study took place in eastern Shizuoka Prefecture, Japan, and included an investigation of the domestic and natural water sources. Polyvinyl chloride (PVC) is a commercial, inexpensive material used for water pipes, and it is compatible with plasticizers, such as diisononyl phthalate (DINP) and tri-octyle trimellitate (TOTM), which make it flexible [1]. However, the microbial and chemical qualities of water passing through polyethylene pipes can not only affect the plastic materials but also cause the migration of various compounds, as plasticizer compounds from PVC tubes have been reported [2-5]. Therefore, plasticized polyvinyl chloride can be attacked by microorganisms [6]. The microorganisms can use the plasticizer as a carbon source; moreover, a favorable growth condition, such as water, temperature, and nutrients, promotes microbial growth [7]. In the last several years, bacterial community succession related to polar cyclic ether (1,4-dioxane and 1,4-dioxin) exposure has been investigated; all these studies have provided valuable information on the potential for biodegradation of polar cyclic ether among various microorganisms [8-12]. Very recently, the bacterial nutrients 1,4-dioxane has emerged as an important water contaminant elsewhere [13-15]. Microbial growth is directly related to the supply of nutrients [16-18]. Le Chevallier et al. [19] indicated that organic carbon has a significant influence on the growth of bacteria in distributed water. In the last several years, however, 1,4-dioxane biodegradation has been reported for pure $[20,21]$ and mixed cultures of bacteria $[22,23]$ as well as for a fungal isolate [24]. Moreover, the simultaneous effect of the $\mathrm{pH}$ and temperature on the growth of heterotrophic bacteria has been determined [16]. It has been shown that it is the plasticizer, and not the plastic itself, that is attacked by the microorganisms [2, 25-28]; the observed embrittlement of the plastic composition was thus explained by the progressive disappearance of the plasticizer. Therefore, it was of interest to investigate this degradation further with a view to elucidating its mechanism with respect to the relationship between the 
amount of organic nutrients and the temperature required to support bacterial growth. In Shizuoka, shower hoses are losing flexibility and becoming hard after just one year of use. As part of a regional study on the mechanism behind the damage to PVC shower hoses in Shizuoka (Japan), damaged hoses and water samples of raw, treated, and distributed water were collected from 34 stations from eastern Shizuoka to identify the reason for the damage. Eastern Shizuoka is one of the major industrial centers of Shizuoka Prefecture, and Fuji City has hosted numerous chemical plants, life science industries, and 85 highly developed paper factories including Nippon Paper Industries and the Oji Paper Company, since the Meiji period. In paper manufacturing, large amounts of polar cyclic ether (1,4-dioxane and 1,4-dioxin) is widely used as an industrial solvent and a solvent stabilizer. Likewise, organic pollutants from the paper-recycling process have been identified and quantified from the water discharge area in Fuji City [29-31]. However, the effect of these large contaminant plumes threatening domestic water supplies that are near the original release sites has not been investigated. As this new damage was only found on the inside of shower hoses in Shizuoka, we have selected the following parameters for investigation: 1) chemical changes in damaged hoses; 2) Shizuoka water quality (physicochemical and microbial); and 3) shower water temperature. However, we are the first investigator, requested by hose manufacturing company to investigate this new intricate damage problem and it can be assumed that environmental factors are of great importance in determining the mechanism of damage. This investigation research is based on the assessment carried out by analytical and material characterization methods. The purposes of this study are to identify the unknown chemical changes in damaged shower hoses and clarify the effect of water fluid on the damage mechanism on the basis of the quality of Shizuoka water.

\section{Materials and Methods}

\subsection{Study Area Description}

Shizuoka's boundaries are $155 \mathrm{~km}$ from east to west and $118 \mathrm{~km}$ from north to south (Figure 1(a)), which is located on the coast of Suruga Bay in the Pacific Ocean, has one of the leading paper industries in Japan and has the full range of Japanese geographical oceanic climates. We investigated the quality of water from 34 stations in 11 affected cities (1. Suntou-gun ${ }^{\mathrm{St}(1-3)}, 2$. Gotenba $^{\mathrm{St}(4-6)}, 3 \mathrm{a}$.

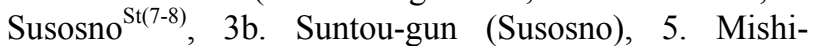
$\mathrm{ma}^{\mathrm{St}(9-13)}$, 7. Atami, 8. Numazu ${ }^{\mathrm{St}(14-15)}$, 19) Fuji $\left.{ }^{\mathrm{St}(16-20)}, 20\right)$ Fujinomiya $^{\mathrm{St}(21-31)}$, x) Fujiyoshida ${ }^{\mathrm{St}(32-33)}$, 24. A. Sidagun, and 24.b. Shizuoka-shi) from eastern Shizuoka located between latitudes $35^{\circ} 07^{\prime} 0.9^{\prime \prime} \mathrm{N}$ and $35^{\circ} 28^{\prime} 15.4^{\prime \prime} \mathrm{N}$ and longitudes $138^{\circ} 33^{\prime} 44.0^{\prime \prime} \mathrm{E}$ and 138 59'10.9"E (Figure 1(b)).
In Figure 1(a), affected cities are marked by black circle and red marker denotes the paper mills locations.

\subsection{Materials and Experimental Techniques}

All chemicals and standards were of the highest purity grade, and MilliQ water (resistivity 18.2 M $\Omega$ ) was used during the experiments. The internal standard and VOC mixes (containing $23 \mathrm{VOCs}$ ) for the calibration of GC-MS, major ion standard solution were purchased from Kanto Co., Ltd. (Japan). Figure 2(a) shows the location of the damage to the hose inside the shower system. The bacteria formation was studied in laboratory on new PVC hose surface at temperatures at $25^{\circ} \mathrm{C}$ and $37^{\circ} \mathrm{C}$ (Figure 2(b)). The water flow was controlled by peristaltic pump. The reservoir (flat bottom volumetric flux) of this system was filled twice a week with tap water originating from Shizuoka water plant. Similar physical changes were observed in the laboratory-analyzed hoses (Figure 2(b)) as the damaged shower hoses (Figure 2(a)) collected from Shizuoka prefecture. The high-temperature area was stiffer than the lower-temperature area of the analyzed PVC hoses (Figure 2(b)). However, to observe the physical and chemical changes in used shower

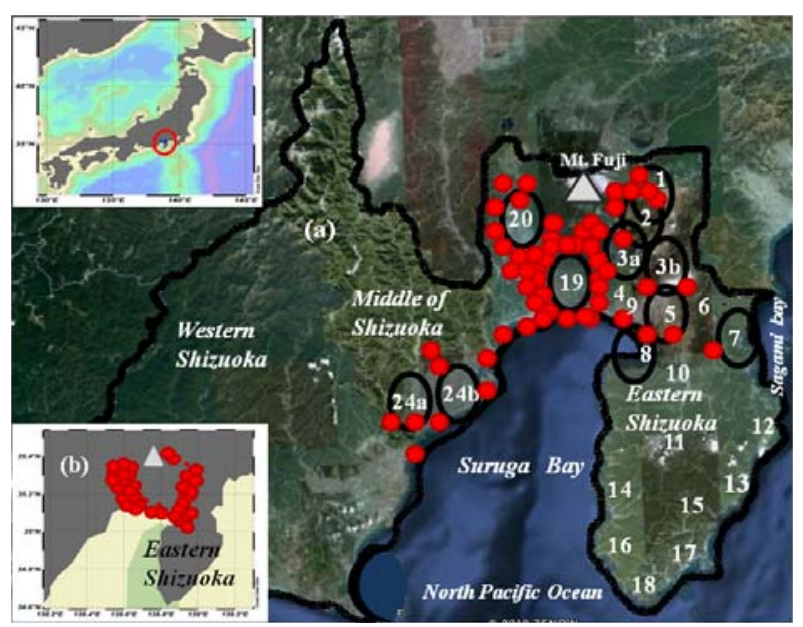

Figure 1. Surveyed area (Shizuoka, Japan): affected cities (O), (a) paper mills(•), (b) sampling station (•).

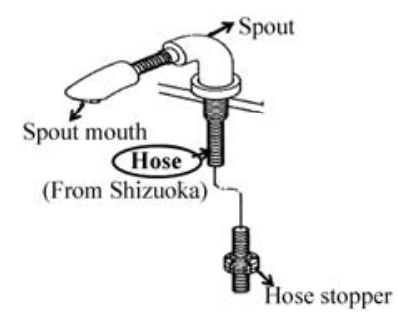

(a)

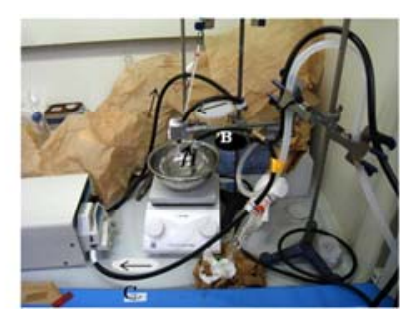

(b)
Figure 2. Shower hose (in Shizuoka) and (b) an apparatus setup for hose analysis. 
hoses, a continuous hot and cold water flow system through new hoses was designed in our laboratory (Figure $2(\mathbf{b}))$.

We measured the elements and their concentration in PVC hoses using a Wavelength-Dispersive X-ray fluorescence (WD-XRF) (PW 2404R, PHILIPS) machine. The carbon $(\mathrm{C})$ and hydrogen $(\mathrm{H})$ weight $\%$ were determined with a CHNS analyzer (VarioMICRO-cube TYU).

The surface characteristics were analyzed using FE-SEM (JEOL, FE-SEM 6700F). The elemental composition can be determined with an energy-dispersive X-ray spectrometer (EDS, JED-2200). The elements O, $\mathrm{C}$, and $\mathrm{Cl}$ were determined in this work. Acceleration voltage of $15 \mathrm{kV}$ and a beam current of $6 \times 10^{-8} \mathrm{~A}$ were used in the FESEM / EDS analyses.

Major ions were determined by 761-compact ion chromatography (IC). Cation analysis was performed using a TSK gel IC cation 1/2 HR column (No. J902830), a sample flow rate of $0.8 \mathrm{~mL} / \mathrm{min}$ and electrical conductivity (EC) $487.86 \mu \mathrm{S} / \mathrm{cm}$. Anion analysis was performed using a Shodex IC SI-90 4E column (No. J007842), sample flow rate of $1.3 \mathrm{~mL} / \mathrm{min}$ and EC: $13.76 \mu \mathrm{S} / \mathrm{cm}$. Injection volumes were $20 \mu \mathrm{L}$ for both anion and cation analysis. GC-MS analysis was conducted with a Shimadzu (Japan) model GC-17A gas chromatograph coupled to a Shimadzu model GCMS-QP5050 mass spectrometer. The instrument was operated in the electron ionization mode at $70 \mathrm{eV}$, an ion source temperature of $240^{\circ} \mathrm{C}$, a mass range of 10 to 900 , scan range of $60-600 \mathrm{~m} / \mathrm{z}(1$ sec interval), sensitivity $100 \mathrm{pg}$, maximum scanning speed $6.750 \mathrm{u} / \mathrm{sec}$ (for single scan).

Bacterial growth was enriched on PVC hose surface, exposed to hot water about one month and the total bacterial DNA concentration was measured by using PCR method. For the determining of DNA concentration of bacterial DNA-containing PVC hose, we performed some steps were as follows: the scissor was washed using $\mathrm{C}_{2} \mathrm{H}_{5} \mathrm{OH}$, then the analyzed hose $(3 \mathrm{~cm}$ long) was washed with $\mathrm{C}_{2} \mathrm{H}_{5} \mathrm{OH}$, cut the hose by sterilized scissor into $1 \mathrm{~cm}$ pieces $(3 / 3=1 \mathrm{~cm})$, insert the $1 \mathrm{~cm}$ long hose into $15 \mathrm{ml}$ centrifugal tube, then DNA extraction is done by phenol - chloroform method.

Bacterial community responsible for shower hose degradation can be detected from shower water by the PCR-DGGE method. The media were a standard medium (Nissui) and an agar medium (Difco). The culture conditions were as follows: temperature, $20^{\circ} \mathrm{C}$; incubation, 2 days; sample volume, $10-20 \mu \mathrm{l}$. Bacterial cells were collected from $100 \mathrm{~mL}$ of shower water samples by filtration using filters with a pore size of $0.2 \mu \mathrm{m}$. After filtration, the filters were transferred into $15 \mathrm{~mL}$ centrifuge tubes and stored at $-20^{\circ} \mathrm{C}$ until DNA extraction. DNA extractions were performed with the phenol-chloroform method [32]. The filtered samples were subjected to freeze and thaw cycles three times. One $\mathrm{mL}$ of lysozyme (Worthington Biochemical Co.; $10 \mathrm{mg} / \mathrm{mL}$ in Tris-HCl, $\mathrm{pH}$ 8.0) was then added, and the samples were mixed and incubated at room temperature. After $5 \mathrm{~min}$ of incubation, $1 \mathrm{~mL}$ of an NE buffer ( $0.15 \mathrm{M} \mathrm{NaCl}, 0.1 \mathrm{M}$ EDTA), 50 $\mu \mathrm{L}$ of RNase (Sigma-Aldrich Co.; $20 \mathrm{mg} / \mathrm{mL}$ ), and $50 \mu \mathrm{L}$ of $20 \%$ SDS were added, and incubation proceeded at 60 ${ }^{0} \mathrm{C}$ for $10 \mathrm{~min}$. Then, $50 \mu \mathrm{L}$ of proteinase $\mathrm{K}$ (Takara Bio, Inc.; $20 \mathrm{mg} / \mathrm{mL}$ ) was added and incubated at $50^{\circ} \mathrm{C}$ for 5 min. After centrifugation at $3500 \mathrm{rpm}$ for $5 \mathrm{~min}$ at room temperature, the supernatants were extracted with an equal volume of TE-saturated phenol (Nippon Gene Co.), phenol-chloroformisoamylalcohol (25:24:1), and chloroform. The aqueous phase was finally precipitated with 0.7 volume isopropanol by centrifugation at $13,000 \mathrm{rpm}$ for $15 \mathrm{~min}$ at $4^{\circ} \mathrm{C}$, and the pellet was washed with $70 \%$ ethanol and resuspended in $200 \mu \mathrm{L}$ of the TE buffer (10 $\mathrm{mM}$ Tris- $\mathrm{HCl}$ [pH 8.0], $1 \mathrm{mM}$ EDTA). Bacterial cells in the 100-lL liquid culture medium were collected by centrifugation, and DNA extraction was performed by the above procedure for the filtered seawater samples. The variable V3 region of the bacterial 16S rDNA was amplified by PCR with primers 341F (5'-CCTACGGGAGGC AGCAG- $\left.3^{\prime}\right)$ and 518R (5'-ATTACCGCGGCT GCTGG3') [32]. A 40-bp GC clamp (5'-CGCCCGCCGCGCCC CGCGCCCGTCCCGCCGCCCCCGCCCG-3') was added to the $5^{\prime}$ end of the $341 \mathrm{~F}$ primer. The amplification reaction was performed in a $40-\mu \mathrm{L}$ reaction mixture containing a $1 \times$ PCR buffer, $0.5 \mu \mathrm{M}$ for each primer, $0.2 \mathrm{mM}$ dNTPs, 1 U of Takara Ex Taq HS (Takara Bio, Inc.), and $2 \mu \mathrm{L}$ of a DNA template solution. PCR amplification was carried out by initial denaturation at $94^{\circ} \mathrm{C}$ for $3 \mathrm{~min}$ followed by 35 cycles at $94^{\circ} \mathrm{C}$ for $1 \mathrm{~min}, 60^{\circ} \mathrm{C}$ for $1 \mathrm{~min}$, and $72^{\circ} \mathrm{C}$ for $1 \mathrm{~min}$ and final extension at $72^{\circ} \mathrm{C}$ for $3 \mathrm{~min}$ and then held at $15^{\circ} \mathrm{C}$. The PCR products were analyzed for quality and concentration by electrophoresis on $2 \%$ $(\mathrm{w} / \mathrm{v})$ agarose gels stained with ethidium bromide. DGGE was performed with a D-code system (Bio-Rad Laboratories, Inc.) in accordance with the manufacturer's instructions. The PCR products were loaded onto $8 \%(\mathrm{w} / \mathrm{v})$ polyacrylamide gels in a $0.5 \times$ TAE buffer diluted from $50 \times$ TAE buffer ( $2 \mathrm{M}$ Tris base, $2 \mathrm{M}$ glacial acetic acid, and $50 \mathrm{mM}$ EDTA). The polyacrylamide gels were made with a denaturing gradient ranging from $25 \%$ to $65 \%$ (where a $100 \%$ denaturant contains $7 \mathrm{M}$ urea and $40 \%$ formamide). Electrophoresis was carried out at $60^{\circ} \mathrm{C}$ for $12 \mathrm{~h}$ at $70 \mathrm{~V}$, after which the gels were stained with ethidium bromide and photographed on a UV transillumination table with a Multi-Doc-it system (UVP, Inc.).

\section{Results and Discussion}

We developed a plan to research the brittleness in PVC 
hoses; first, we characterized the damaged hoses collected from Shizuoka Prefecture using different analysis methods and confirmed any chemical differences between these hoses and new ones. Then, to clarify any chemical and physical changes to the hoses that took place during their use in Shizuoka, a laboratory study was undertaken to investigate the hardness of the PVC. Finally, we studied the effects of a microbial process in conjunction with the physicochemical properties of Shizuoka water on the degradation of the hose.

\subsection{Compare the Elemental Concentration}

The element (C, H, Cl, O, Ca, $\mathrm{Zn}, \mathrm{Si}$, and $\mathrm{Mg}$ ) compo sitions of damaged and new hoses were obtained by X-ray fluorescence using a Wavelength-Dispersive XRF spectrometer and CHNS. The main elemental compositions are $\mathrm{C}, \mathrm{H}, \mathrm{Cl}$, and $\mathrm{O}$ with lesser amounts of $\mathrm{Zn}, \mathrm{Al}$, $\mathrm{Si}$, and $\mathrm{Mg}$. Carbon and hydrogen were measured with a CHNS analyzer. Shower hoses are made of PVC (56.53\%), plasticizer (DINP: 39.5\%), and other materials, such as epoxidized soya bean oil $(1.7 \%)$, a stabilizer $(1.13 \%)$, a lubricant $(0.2 \%)$, pigment $(0.45 \%)$, and a filler. In the carbon concentration is less in damaged than in new hoses. As illustrated, the weight percent of oxygen decreased after the degradation of the PVC hose, whereas the chloride concentration appeared to increase. The reduction in oxygen is equivalent to the increase in the amount of chloride for the total sum of the elements of damaged hoses using the WD-XRF machine. Consequently, the chloride concentration of the damaged hose had not changed, which indicates that the original structure of the PVC hose had not been modified by the water quality. The carbon and oxygen concentrations had decreased in the used hose, which indicates that the plasticizer had leached out of the hose and the hose had become hardened. This is because the plasticizer, which contains oxygen and carbon, softens the PVC hose. The exposed parts of the hose in hot water became hardened,

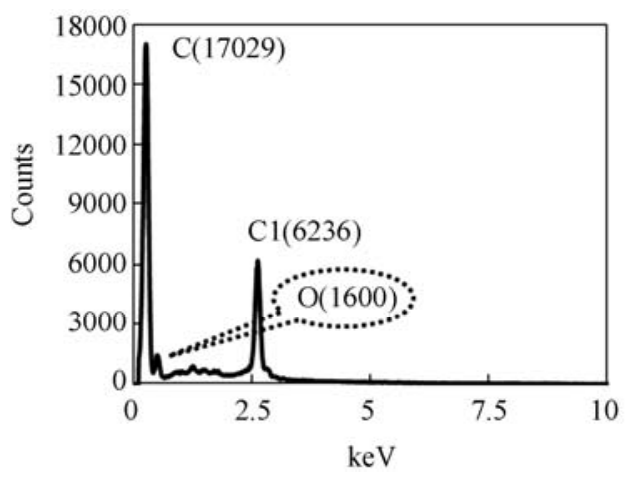

(a) whereas the unexposed parts in hot water were almost unaffected (Figure 2(b)). The carbon and oxygen concentrations were lower in the parts exposed to hot water $(\mathrm{B}<\mathrm{C})$ than in those exposed to water at room temperature (Figure 2(b)), which indicates the importance of temperature relative to the stiffness of the PVC hose.

\subsection{FE-SEM Mapping / EDS}

FE-SEM is a promising tool for the visualization of structures and phenomena of surface characteristics. FESEM/EDS was used to obtain information that would explain the stiffness and elemental changes in structure occurring in PVC hoses. Figure 3(a) and Figure 3(b) show the FE-SEM images and chloride $(\mathrm{Cl})$ mapping of new and used PVC hose surfaces respectively. According to the EDS peak count (Figure 3(a) and Figure 3(b)); the oxygen and carbon counts for stiffed damaged hoses were lower than those in new ones. It is possible that carbon and oxygen in the compound plasticizer in the PVC hose disappear, and, as a result, the level of those materials is lower in damaged PVC hoses; in addition, oxygen is a structural element in the plasticizer molecules in PVC hoses.

\subsection{Bacterial DNA Concentrations}

Bacterial DNA concentration on PVC hose surface was measured by PCR method and the quantified DNA concentration was different for the different surface of the PVC hose exposed to hot $\left(37^{\circ} \mathrm{C}, \mathrm{B}\right.$ surface $)$ and cold $\left(25^{\circ} \mathrm{C}\right.$ surface) water in laboratory-analyzed hose (Figure 2(b)). The highest DNA concentration was found in sample B. The DNA concentration was different in the samples analyzed in the laboratory: $\mathrm{B}(7.4 \mathrm{ng} / \mu \mathrm{g})>\mathrm{C}(2.2$ $\mathrm{ng} / \mu \mathrm{g})$. Here, the B side was made to contact hot water, but not the $\mathrm{C}$ side (Figure 2(b)), and, after one month of continuous water flow through the PVC hose, the B area became harder than the $\mathrm{C}$ area, and the oxygen concentration also decreased inside sample B more than it did in

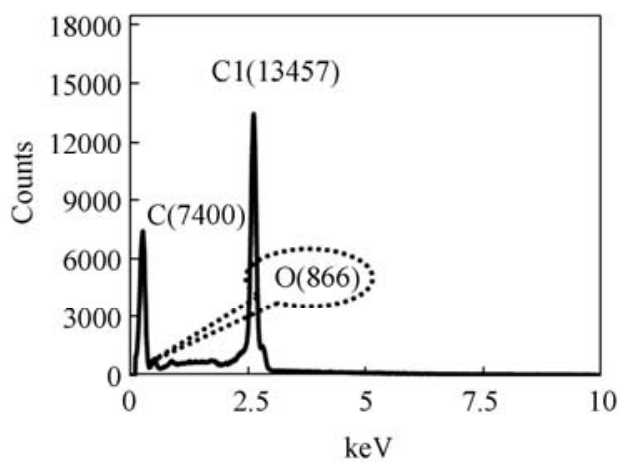

(b)

Figure 3. EDS Peak: (a) new hose; (b) stiffed hose. 
sample $\mathrm{C}$ and a new hose. The highest DNA concentration, $7.4 \mathrm{ng} / \mu \mathrm{g}(\mathrm{B})$, was detected on PVC hose surface after 4 weeks' exposure to hot water $\left(37^{\circ} \mathrm{C}\right)$. A.W. Mayo and T. Noike [16] recommended the incubation temperature of $35^{\circ} \mathrm{C}(72 \mathrm{~h})$ with $\mathrm{pH} 7.0$, for heterotrophic bacteria [16].

According to bacterial analysis, four types of bacteria were detected in shower water with their association number: 1) Pseudomonas fluorescens, 2) Pseudomonas sp., 3) Alpha proteobacterium SKA54 (Citreimonas sp.), and 4) Alpha proteobacterium IMCC10422 (Candidatus Pelagibacter ubique) (Table 1). However, Citreimonas sp. and Candidatus Pelagibacter ubique were not possible to culture, although their concentration was higher in Shizuoka tap water samples. However, the lower concentrations of Pseudomonas fluorescens and Pseudomonas sp. could form colonies on agar. According to the SAR11 clade $[33,34]$ consists of very small, heterotrophic marine proteobacteria that are found throughout the oceans, where they account for about $25 \%$ of all microbial cells. The detected marine bacteria (SAR11 clade) were unable to form colonies on agar surfaces. These bacteria exhibited a behavior that promotes growth and dispersal rather than colony formation [33]. The term "heterotrophic bacteria" includes all bacteria that use organic nutrients for growth $[16,19]$. Because heterotrophic bacteria require carbon, nitrogen, and phosphorous in a ratio of approximately 100:10:1 (C: N: P) [19]. Shizuoka tap water contains heterotrophic bacteria as well as the rich organic nutrient 1,4-dioxane.

\subsection{Major ions and Physicochemical Parameters for Shizuoka Water}

The major ions compositions and contents were similar for similar sampling stations in eastern Shizuoka. However,

Table 1. Identification of bacteria in shower water.

\begin{tabular}{cccc}
\hline Types & Name & Accession No & Match (\%) \\
\hline $\begin{array}{l}\text { Before culture the shower water, only DGGE band (A) and band (B) } \\
\text { were detected }\end{array}$ & & \\
DGGE & alpha proteobacterium & AY317121 & $126 / 128(98 \%)$ \\
band (A) & $\begin{array}{c}\text { SKA54 } \\
\text { (Citreimonas sp.) }\end{array}$ & (GU213182) & $124 / 128(96 \%)$ \\
& $\begin{array}{c}\text { alphaproteobacterium } \\
\text { DGGE }\end{array}$ & FJ532495 & $120 / 120(100 \%)$ \\
band (B) & $\begin{array}{c}\text { (Candidatus } \\
\text { Pelagibacter ubique) }\end{array}$ & (EU410957) & $120 / 120(100 \%)$
\end{tabular}

After culture on agar, the detected colonies (A and B were not possible to culture on agar):

\begin{tabular}{lccc} 
Colony-1 & $\begin{array}{c}\text { Pseudomonas } \\
\text { fluorescens }\end{array}$ & GU177878 & 466/468 (99\%) \\
Colony-2 & Pseudomonas sp. & FM161392 & $451 / 465(96 \%)$ \\
\hline
\end{tabular}

major ion compositions varied according to the station locations in relation to paper industrial sites. Instead, the increased major ion concentrations $\left(\mathrm{NO}_{3}{ }^{-}, \mathrm{SO}_{4}{ }^{-2}, \mathrm{Na}^{+}\right.$, $\mathrm{Ca}^{+2}, \mathrm{Mg}^{+2}$ ) may be due to contamination from the paper industry as the concentrations are higher in areas with paper industries.

Figure 4 represents the water sampling station versus electrical conductivity (EC) (Figure 4(a)), $\mathrm{pH}$ (Figure 4(b)) $\mathrm{NO}_{3}$ (Figure 4(c)) and $\mathrm{K}$ versus $\mathrm{NO}_{3}\left(\mathrm{~K}: \mathrm{NO}_{3}=1: 1\right)$ graph from 33 affected sites. The $\mathrm{pH}$ of the water samples ranged from 6.81 to 8.09 . Water samples investigated in this study exhibit high concentrations of $\mathrm{Cl}^{-}, \mathrm{NO}_{3}^{-} \mathrm{NO}_{3}^{-}$, $\mathrm{SO}_{4}^{-2}$, and $\mathrm{HCO}_{3}^{-}$as the major anions and $\mathrm{Ca}^{2+}$ and $\mathrm{Mg}^{2+}$ as the major cations. Tap, river, spring, and pond water from Fuji and Fujinomiya Cities and the Uzui River in this database have high mineralization, as shown by the electrical conductivity measurements (Figure 4(a)), which range from 200 to $340 \mu \mathrm{S} / \mathrm{cm}$. High EC values were also observed at other stations, Gotenba, Mishima, and Nomazu, which are located near Fuji City. The water samples from Fuji, Fujinomiya, and Mishima Cities have high concentrations of $\mathrm{NO}_{3}^{-}$(Figure 4(c)) in domestic and surface water. Moreover, a high concentration of nitrate was detected in tap water at Fujinomiya (near Fuji City); this may be attributed to the local percolation of waste water from industry in the nearby area.

\subsection{VOCs $(\mu \mathrm{g} / \mathrm{L})$ Concentrations}

VOC contamination in the affected cities of eastern Shizuoka are shown in Figure 5. The determined concentrations of aquatic 1,4-dioxane (Figure 5(a)), and tert-butyl ether (Figure 5(b)) VOCs versus pH (Figure 5(c)), are mapped in this Figure 5. Cyclic ether (1,4-dioxane, tert-butyl ether (MTBE, $\left.\mathrm{CH}_{3} \mathrm{OC}\left(\mathrm{CH}_{3}\right)\right)$ ) and chloroform were the dominant compounds detected by GC-MS in various natural water (spring, pond, and river) and domestic water sources (shower water) in eastern Shizuoka Prefecture. The concentrations of 1,4-dioxan and tertbutyl ether, including total volatile organic compounds (VOCs), at 34 sites in March 2010 are shown in Figures 5(a), 5(b) and 5(c). According to GC-MS analysis, the 1,4-dioxane and tert-butyl ether concentrations were higher than those from other VOCs, such as trihalomethane (THMs), toluene, chloroethylene, and xylene. Fuji and Fujinomiya Cities are primarily polluted by cyclic ether. The Uzui river, which runs through Fuji and Fujinomiya City, is one of the most polluted rivers. It is contaminated by polar cyclic ether, 1,4-dioxane (66.6 $\mu \mathrm{g} / \mathrm{L}$, tert-butyl ether $(78.55 \mu \mathrm{g} / \mathrm{L}))$. The possible sources of these cyclic ethers may be paper industries because eastern Shizuoka has highly developed paper and chemical plants along its shores. According to a pollutant release and transfer resister (PRTR) report (April 2007- 


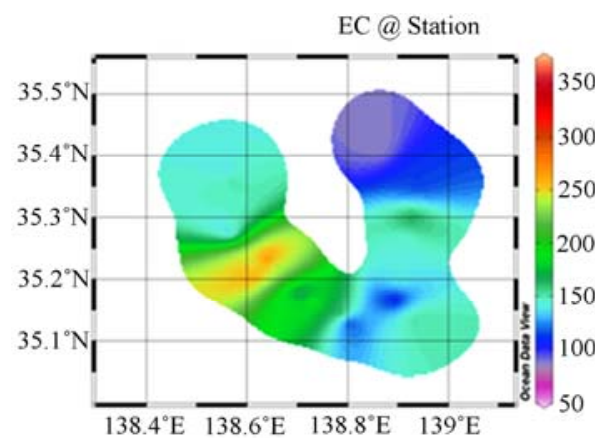

(a)

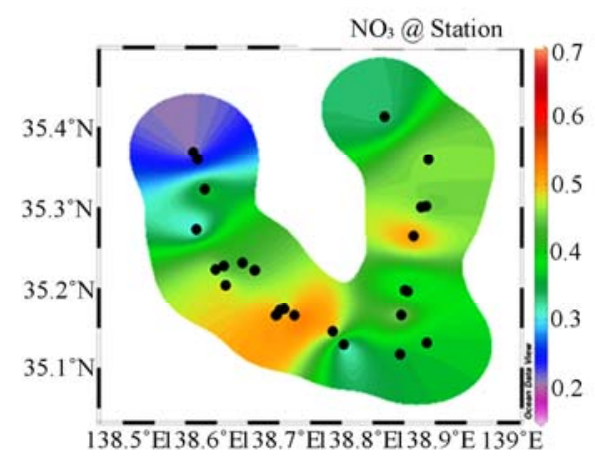

(c)

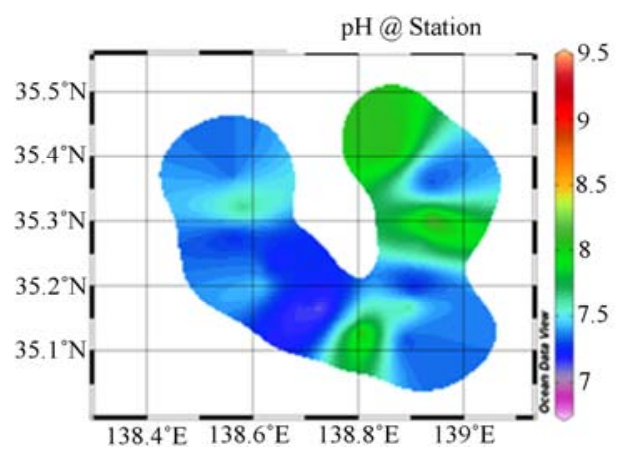

(b)

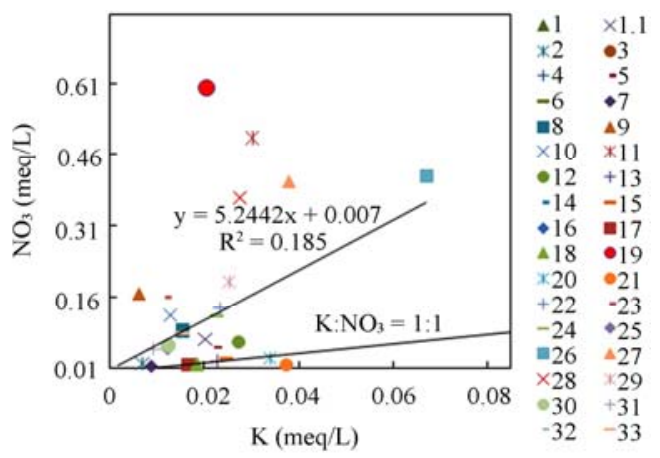

(d)

Figure 4. Physicochemical mapping of Shizuoka water; (a) EC, (b) $\mathrm{pH},(\mathrm{c}) \mathrm{NO}_{3}^{-}$, (d) $\mathrm{K}^{+}: \mathrm{NO}_{3}^{-}=1: 1(\mathrm{meq} / \mathrm{L})$.

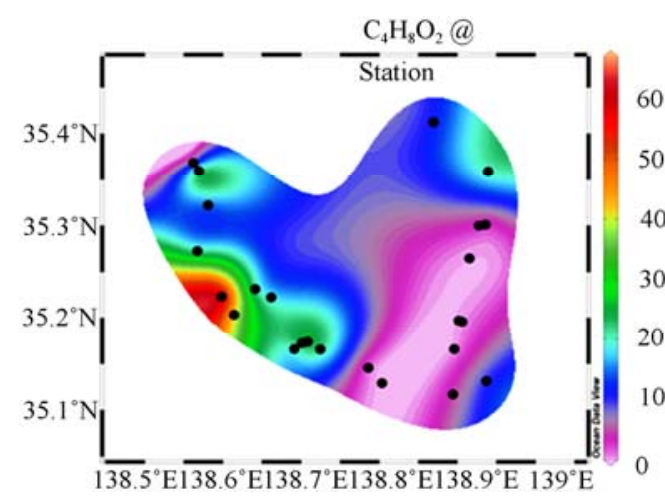

(a)

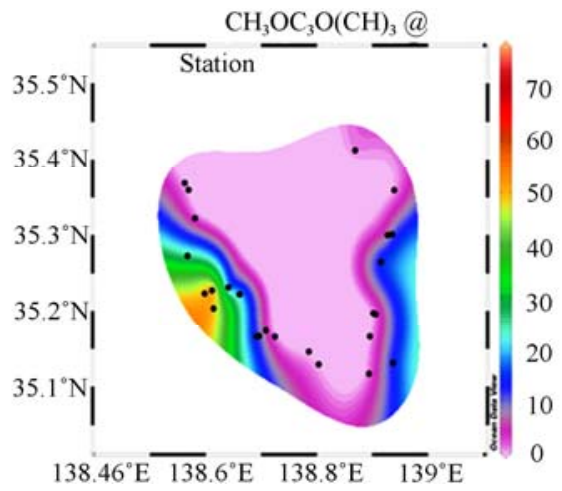

(b)

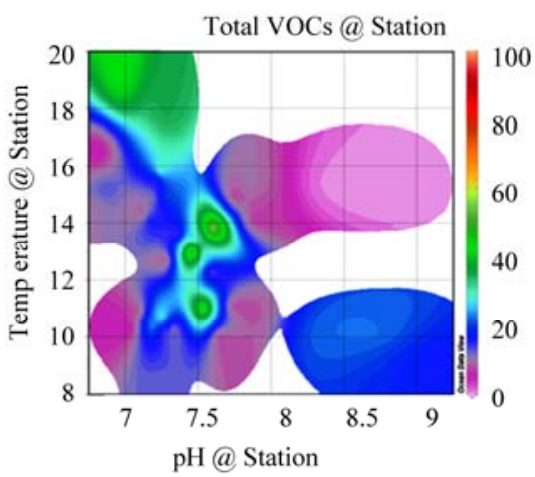

(c)

Figure 5. Distribution of (a) 1,4-dioxane, (b) tert-butyl ether; and (c) Total VOCs versus pH in 34 sampling station in Shizuoka. 
March 2008), the Oji paper mill (Fuji City, Japan) released polar cyclic ether and other organic chemical substances into waste waters following the Japanese standard value. According to a color mapping diagram (Figure 5(a)), samples from tap, river, pond, and spring water from Fuji, Fujinomiya, and Suntou-gun (Koyama) cities and the Uzui river, which runs through Fuji and Fujinomiya Cities, are most contaminated by 1,4-dioxan because the Uzui River $(66.6 \mu \mathrm{g} / \mathrm{L})$ is the mouth of a port connected with outflow from which the river discharges into the Pacific Ocean. The 1,4-dioxane concentration levels were unsatisfactory, with average levels ranging from 1.8 to $66.6 \mu \mathrm{g} / \mathrm{L}$ (Figure 5(a)), whereas Japan has established a standard at $50 \mu \mathrm{g} / \mathrm{l}$. However, bacteria can grow with 1,4-dioxane as a sole carbon source $[35,36]$. We compare the water qualities of unaffected Toyama Prefecture with the water qualities from Shizuoka Prefecture. Cyclic ether (1,4-dioxane) observed for the Shizuoka region, whereas Toyama water (tap, ground, spring) did not contain such kind organic pollutant.

\subsection{Affected Cities and Paper Mill Site in Shizuoka}

PVC shower hoses are becoming hard, particularly in paper mill locations in eastern Shizuoka, where the surface and domestic water sources (tap, pond, river, spring water) have been polluted by 1,4-dioxane and tert-butyl ether (MTBE, $\mathrm{CH}_{3} \mathrm{OC}\left(\mathrm{CH}_{3}\right)$ ). There are 85 pulp, paper, and recycling mills in Fuji City, which is the largest number of paper mills in one area in Japan, and other cities in Shizuoka Prefecture also have pulp and paper mills, as shown in Figure 1(a). PVC shower hoses were reported to have become hardened in 11 cities in eastern Shizuoka Prefecture. Most of the affected cities are located in the pulp and paper mill area (Figure 1(a)). Nine affected cities are in eastern Shizuoka, which is between latitudes $35^{\circ} 07^{\prime} 0.9^{\prime \prime} \mathrm{N}$ and $35^{\circ} 28^{\prime} 15.4^{\prime \prime} \mathrm{N}$ and longitudes $138^{\circ} 33^{\prime} 44.0^{\prime \prime E}$ and 138 59'10.9"E (Figure 1(a)), and two other cities are in central Shizuoka. Other unaffected cities (No. 10 - No.18) from eastern Shizuoka are far from paper industries area. In Figure 2(a), Fuji and Fujinomiya Cities have the most paper mills, and the water from tap, river, pond, and spring sources contains the highest concentration of 1,4-dioxane and tert-butyl ether (MTBE, $\mathrm{CH}_{3} \mathrm{OCCH}_{3}$; relative to those of Toyama, where the water is not contaminated with polar cyclic ether and shower hoses are not affected after being used for a long time.

\subsection{Damage Mechanism}

Plasticizers reduce the polymer-polymer chain secondary bonding and provide more mobility for macromolecules, resulting in a softer, more easily deformable mass.
However, plasticizers (DINP), which contain oxygen and carbon, may leach out from the shower hose. Therefore, the hose becomes hardened, and the concentration of carbon and oxygen decreases in the damaged hoses.

The quality of Shizuoka water is responsible for the hardness of PVC tubes. However, there are 85 paper mills in Fuji City alone, and other affected cities in eastern Shizuoka have paper and pulp mills as well. The polar cyclic ether 1,4-dioxane is widely present in river, pond, and spring water, including shower water, from the possible sources of waste water from paper mills. Shizuoka shower water also contains the most abundant and ubiquitous clade of marine heterotrophic bacteria as well as organic nutrients (cyclic ether). Heterotrophic bacteria can aerobically mineralize 1,4-dioxane as a sole carbon and energy source in minimal salt medium. Therefore, the bacterial growth increased inside the shower hose at shower temperature with rich food 1,4-dioxane and methyl tert-butyl ether, and need to use carbon-based substrate plasticizers (DINP) for the extra energy sources of increasing bacterial growth. Therefore, plasticizer disappeared quickly from the shower hose, causing them to lose flexibility and become hard and brittle.

However, at the incubation conditions, heterotrophic bacterial formation is considerably slower at $20^{\circ} \mathrm{C}$ than at $35^{\circ} \mathrm{C}[16,37]$. However, the most suitable set of incubation condition at $35^{\circ} \mathrm{C}$ with $\mathrm{pH}$ of 7.0 , the number of cells capable of forming colonies significantly to those at $35^{\circ} \mathrm{C}$ and the incubation time at $35^{\circ} \mathrm{C}$ was shorter [16]. According to our laboratory analysis, bacterial DNA concentration on PVC hose surface was higher exposed at $37^{\circ} \mathrm{C}$ (B-surface) compare to at $25^{\circ} \mathrm{C}$ (C-surface) (Figure 2(b)). The decreased concentration of oxygen and carbon for the B-surface is also attributed to the prompt utilization of plasticizer by increased bacteria and thus the part-B become hard for the decreasing amount of plasticizer (Figure 2(b)). Therefore, an understanding of the relative position of the paper mills and the entire affected areas in Shizuoka Prefecture provides useful indicative information on the key processes leading to hardening of shower hoses. Bacterial regrowth formation is a behavior that allows prompt utilization of the substrate. The combined exoenzymatic action of a growing fragment provides benefits to the individual cells when there is a rich food supply [16].

\section{Conclusions}

The carbon and the oxygen concentration decreased in the damaged shower PVC hoses. According to the raw material composition (PVC: plasticizer $=100: 70$ ), plasticizer contain oxygen in its primary structure. Therefore, plasticizer leached out of the PVC hose, and the hose become brittle because the plasticizer softens the PVC 
hose. There are four types of heterotropic bacteria which have been detected in Shizuoka tap water. The 1, 4-dioxane and total VOC concentration, which is known to influence microorganism growth, was higher at a $\mathrm{pH}$ range of 7-7.5 in the affected area. However, 1,4-dioxane can influence the bacterial growth as a sole carbon source. Therefore, heterotrophic bacterial growth increases at shower temperature inside shower hose using organic nutrients from water sources that allows prompt utilization of the plasticizer DINP (substrate) in PVC shower hose which is responsible for stiffness of shower hose. Additionally this heterotrophic bacteria can effectively utilize 1,4-dioxane for bacterial scissions of ether bonds from Shizuoka tap water as a sole carbon and energy source.

\section{Acknowledgements}

The research was financially supported by a grant-in-aid for Scientific Research (No. 19310007) from the Ministry of Education, Science, Sports and Culture of Japan. We are very grateful to Professor Shogo Naka mura, University of Toyama, for bacterial analysis.

\section{REFERENCES}

[1] K. Saeki, K. Funatsu and K. Tanabe, "Discrimination of Poly(Vinyl Chloride) Samples with Different Plasticizers and Prediction of Plasticizer Contents in Poly(Vinyl Chloride) Using Near-Infrared Spectroscopy and Neural-Network Analysis," Analytical Science, Vol. 19, No. 2, 2003, pp. 309-312. doi:10.2116/analsci.19.309

[2] R. H. Wellman and S. E. A. Mccallan, "Fungus Resistance of Plastics," O.S.R.D. Report, 1945.

[3] S. M. Shina, H. S. Jeona, Y. H. Kimb, T. Yoshiokac and A. Okuwakic, "Plasticizer Leaching from Flexible PVC in Low Temperature Caustic Solution," Polymer Degradation and Stability, Vol. 78, No. 3, 2002, pp. 511-517. doi:10.1016/S0141-3910(02)00198-2

[4] M. Ito and K. Nagai, "Analysis of Degradation Mechanism of Plasticized PVC under Artificial Aging Conditions," Polymer Degradation and Stability, Vol. 92, No. 2, 2007, pp. 260-270. doi:10.1016/j.polymdegradstab.2006.11.003

[5] A. Marcilla, S. García, J. C. García-Quesada, "Study of the Migration of PVC Plasticizer," Journal of Analytical and Applied Pyrolysis, Vol. 71, No. 2, 2004, pp. 457-463. doi:10.1016/S0165-2370(03)00131-1

[6] I. Skjevrak, V. Lund, K. Ormerod and H. Herikstad, "Volatile Organic Compounds in Natural Biofilm in Polyethylene Pipes Supplied with Lake Water and Treated Water from the Distribution Network," Water Research, Vol. 39, 2005, pp. 4133-4141. doi:10.1016/j.watres.2005.07.033

[7] E. Bessem, "The Biodeterioration of Plasticized PVC and Its Prevention," Journal of Vinyl Technology, Vol. 10, No. 1, 1988, pp. 3-6. doi:10.1002/vnl.730100103
[8] D. Shin; D. Y. Sung, H. S. Moon and K. Nam, "Microbial Succession in Response to 1,4-Dioxane Exposure in Activated Sludge Reactors: Effect of Inoculum Source and Extra Carbon Addition," Journal of Environmental Science and Health, Part A, Vol. 45, No. 6, 2010, pp. 674-681.

[9] A. Hiraishi, "Biodiversity of Dioxin-Degrading Mi Croorganisms and Potential Utilization in Bioremediation," Microbes and Environments, Vol. 18, 2003, pp. 105-125. doi:10.1264/jsme2.18.105

[10] H. Nojiri, and T. Omori, "Molecular Bases of Aerobic Bacterial Degradation of Dioxins: Involvement of Angular Dioxygenation," Bioscience Biotechnology Biochemistry, Vol. 66, 2002, pp. 2001-2016. doi: $10.1271 / \mathrm{bbb} .66 .2001$

[11] S. Mahendra and L. Alvarez-Cohen, "Kinetics of 1,4-Dioxane Biodegradation by MonooxyGenase-Expressing Bacteria," Environmental Science and Technology, Vol. 40, 2006, pp. 5435-5442. doi:10.1021/es060714v

[12] S. Mahendra, C. J. Petzold, E. E. Baidoo, K. D. Keasling and L. Alvarez-Cohen, "Identification of the Intermediates of in Vivo Oxidation of 1,4-Dioxane by Monooxygenase-Containing Bacteria," Environmental Science and Technology, Vol. 41, 2007, No. 12, pp. 7330-7336. doi:10.1021/es0705745

[13] S. Vainberg, K. McClay, H. Masuda, D. Root, C. Condee, J. G. Zylstra and J. R. Steffan, "Biodegradation of Ether Pollutants by Pseudonocardia sp. Strain ENV478," Applied and Environmental Microbiology, Vol. 72, No. 8, 2006, pp. 5218-5224. doi:10.1128/AEM.00160-06

[14] K. Kawata and A. Tanabe, "Distribution and Variation of 1,4-Dioxane in Water from Rivers in Niigata Including the Shinano River," Bulletin of Environmental Contamination and Toxicology, Vol. 82, No. 6, 2009, pp. 673-677. doi:10.1007/s00128-009-9697-5

[15] R. Makino, H. Kawasaki, A. Kishimoto, M. Gamo and J. Nakanishi, "Estimating Health Risk from Exposure to 1,4-Dioxane in Japan," Environmental Science and Tec nology, Vol. 13, No.1, 2006, pp. 43-58.

[16] A. W. Mayo and T. Noike, "Effects of Temperature and $\mathrm{pH}$ on the Growth of Heterotrophic Bacteria in Waste Stabilization Ponds," Water Research, Vol. 30, No. 2, 1996, pp. 447- 455. doi:10.1016/0043-1354(95)00150-6

[17] P. C. Miller and T. R. Bott, "Effects of Biocide and Nutrient Availability on Microbial-Contamination of Surfaces in Cooling-Water Systems," Journal of Chemical Technology \& Biotechnology, Vol. 32, No. 4, 1982, pp. 538-546.

[18] M. G. Trulear and W. G. Characklis, "Dynamics of Biofilm Processes," Water Pollution Control Federation, Vol. 54, 1982, No. 9, pp. 1288-1301.

[19] W. M. Lechevallier, W. Schulz and R. G. Lee, "Bacterial Nutrients in Drinking Water," Applied Environmental Microbiology, Vol. 57, 1991, pp. 857-862.

[20] R. E. Parales, J. E. Adamus, N. White and H. D. May, "Degradation of 1,4-Dioxane by an Actinomycete in Pure 
Culture," Applied Environmental Microbiology, Vol. 60, 1994, pp. 4527- 4530.

[21] D. Bernhardt and H. Diekmann, "Degradation of Dioxane, Tetrahydrofuran and Other Cyclic Ethers by an Environmental. Rhodococcus Strain," Applied Environmental Microbiology, Vol. 36, 1991, pp. 120-123.

[22] G. M. Klecka and S. J. Gonsior, "Removal of 1,4-Dioxane from Wastewater," Journal of Hazardous Materials, Vol. 13, 1986, pp. 161-168. doi:10.1016/0304-3894(86)80016-4

[23] M. J. Zenker, R. C. Borden and M. A. Barlaz, "Mineralization of 1,4-Dioxane in the Presence of a Structural Analog," Biodegradation, Vol. 11, 2000, pp. 239-246. doi:10.1023/A:1011156924700

[24] K. Nakamiya, S. Hashimoto, H. Ito, J. Edmonds and M. Morita, "Degradation of 1,4-Dioxane and Cyclic Ethers by an Isolated Fungus," Applied and Environmental Microbiology," Vol. 71, 2005, pp. 1254-1258. doi:10.1128/AEM.71.3.1254-1258.2005

[25] M. W. LeChevallier, B. H. Olson and G. A. McFecters, "Assessing and Controlling Bacterial Regrowth in Distribution Systems," Journal of American Water Works Association, Vol. 82, 1990, pp. 145-201.

[26] R. H. Wellman and S. E. A. Mccallan, "Fungus Resistance of Plastics," O.S.R.D. Report, 1945.

[27] D. M. Molnar and J. M. Leonard, "Tropical Deterioration of Materials for Electrical Equipment, Part 1.Plasticizers," Naval Research Laboratory Report, Washington D.C., 1995, pp. 2492.

[28] A. E. Brown, "The Problem of Fungal Growth on Synthetic Resins, Plastics and Plasticizers," O.S.R.D. Report, MCI, 1945.

[29] J. V. Harvey and F. J. Meloro, "Studies on Degradation of Plastic Films by Fungi and Bacteria," Quartermaster Laboratory Report, Microbiological Series, Washington D.C., 1949.
[30] M. Terasaki, F. Shiraishi, H. Fukazawa and M. Makino, "Occurrence and Estrogenicity of Phenolics in $\mathrm{Pa}$ per-Recycling Process Water: Pollutants Originating from Thermal Paper in Waste Paper," Environmental Toxicology and Chemistry, Vol. 26, 2007, pp. 2356-2366. doi:10.1897/06-642R.1

[31] M. Terasaki, H. Fukazawa, Y. Tani and M. Makino, “Organic Pollutants in Paper-Recycling Process Water Discharge Areas: First Detection and Emission in Aquatic Environment," Environmental Pollution, Vol. 151, 2008, pp. 53-59. doi:10.1016/i.envpol.2007.03.012

[32] D. Tanaka, S. Tanaka, Y. Yamashiro and S. Nakamura, "Distribution of Oil-Degrading Bacteria in Coastal Seawater, Toyama Bay, Japan," Environmental Technology, Vol. 23, 2008, pp. 563-569.

[33] K. Simu and A. Hagström, "Oligotrophic Bacterioplankton with a Novel Single-Cell Life Strategy," Applied Environmental Microbiology, Vol. 70, 2004, pp. 2445-2451. doi:10.1128/AEM.70.4.2445-2451.2004

[34] S. J. Pirt, "Principles of Microbe and Cell Cultivation," Blackwell, London, 1971

[35] A. A. Esener, J. A. Roels and N. W. F. Kossen, "The Influence of Temperature on the Maximum Specific Growth Rate of Klebsiella Pneumonia," Biotechnology and Bioengineering, Vol. XXIII, 1981, pp. 1401-1405. doi: 10.1002/bit.260230620

[36] S. Mahendra and L. Alvarez-Cohen, "Kinetics of 1,4-Dioxane Biodegradation by MonooxyGenase-Expressing Bacteria," Environmental Science and Technology, Vol. 40, No. 17, 2006, pp. 5435-5442. doi:10.1021/es060714v

[37] M. Ito and K. Nagai, "Analysis of Degradation Mechanism of Plasticized PVC under Artificial Aging Conditions," Polymer Degradation and Stability, Vol. 92, 2007, pp. 260-270. doi:10.1016/j.polymdegradstab.2006.11.003 